Poznań

\title{
Szkoła demokracji - młodzież w świecie społeczno-politycznym. Wykluczenie, czy zaniedbanie?
}

\section{Demokratyczna legitymacja. W poszukiwaniu elektoratu}

$\mathrm{J}^{\mathrm{c}}$ edna z podstawowych zasad tzw. demokratycznego porządku, wskazuje obywatelom danego państwa, konieczność cyklicznego wyboru swoich przedstawicieli, którzy w ich imieniu sprawować będą rządy. W systemach określanych jako demokracje, wspomniana procedura jest realizowana na podstawie prawa (np. ordynacji wyborczej), mniej więcej raz na cztery lub pięć lat. W najważniejszym polskim akcie prawnym - Konstytucji, zawarte są najistotniejsze (oprócz powszechności) przymiotniki procesu wyborczego. Ustawa Zasadnicza ${ }^{1}$, nakazuje, aby wybory były: powszechne, równe, bezpośrednie i by odbywały się w głosowaniu tajnym. Realizacja powyższych, traktowana jest jako warunek sine qua non uznania całego procesu, za zgodny z prawem. Nie jest to jednak warunek wystarczający, aby można było mówić o pełnej legitymizacji wybranej władzy. W praktyce politycznej, ważne jest także, jak duże poparcie (w skali kraju lub regionu) osiagnęła dana partia, organizacja, czy też lider. A więc zwraca się uwagę na to: jaka liczba osób oddała swój głos na dany projekt czy konkretną osobę. Można zatem powiedzieć, iż siła społecznego mandatu, będzie uzależniona od tego, czy zwycięstwo wyborcze nie jest oparte na relatywnie niedużej liczbie głosów, albo czy nie zostało ono osiagnięte $\mathrm{z}$ niewielką jedynie ich przewagą ${ }^{2}$. W przypadku

1 Art. 96 ust 2 Konstytucji RP z dnia 2 kwietnia 1997 r. (Dz. U. Nr 78, poz. 483) za: http://www.pkw.gov.pl/gallery/19/91/72/199172/Konstytucja_Rzeczypospolitej_Polskiej.pdf, dostęp 20.06.2011.

2 Choć niektórzy autorzy - jak np. C. Offe (1984) - wyrażają wątpliwość co do uniwersalnego zastosowania zasady większości w nowych demokracjach. Wspomniany autor, twierdzi m.in. że ,zasada większości dopuszczalna jest jedynie tam i wtedy, gdzie mocne pozycje dotychczasowej władzy i jej możliwości sprzeciwu są zakorzenione w strukturach społecznych i dają gwarancję tego, że nie naruszy so- 
wyboru władzy o słabym mandacie politycznym, możemy być świadkami odmowy podporządkowania się jej lub też kwestionowania jej decyzji; w postaci choćby tzw. aktów obywatelskiego nieposłuszeństwa.

Podsumowując, można zatem postawić tezę, iż partie, czy liderzy będą robić wszystko w celu zapewnienia sobie odpowiednio dużej przewagi (głosów), tak aby siła ich społeczno-politycznego umocowania była jak największa. Realizując ten postulat, konieczne jest jak najszersze otwarcie się przywódców na elektorat. Rozpoczęcie kampanii wyborczej, zwykle jest czasem wzmożonej eksploracji i poszukiwania poparcia wśród grup dotychczas zapomnianych, czy pomijanych. Jedną z takich kategorii, o której politycy zwykle przypominają sobie podczas prowadzenia kampanii są ludzie młodzi.

Oni sami, zaczęli być postrzegani jako autonomiczna kategoria społeczno-polityczna, dopiero na początku ubiegłego wieku - czasu powojennego boomu gospodarczego w Stanach Zjednoczonych i procesów bogacenia się klasy średniej i robotniczej. Ówczesne warunki otworzyły możliwości, w których młodzi ludzie z tych środowisk, podejmując prace zarobkowe zaczęli dysponować własnym kapitałem, tworząc mimowolnie grupę docelową - tzw. target dla firm i koncernów przemysłowych. Podmioty te, chcąc zebrać jak najwięcej danych dotyczących tej zbiorowości, tak aby zaoferować jej jak najlepiej „skrojony” produkt - rozpoczęły własne eksploracje. Tak rozpoczęła swoje istnienie nowa kategoria społeczna - młodzi. Nauka odnotowała i zaimplementowała to zjawisko dostosowując je do własnych potrzeb badawczych już na przełomie lat 40. i 50., wprowadzając do opisu tejże zbiorowości termin: teenager - polski odpowiednik: nastolatek ${ }^{3}$. Termin ten, w późniejszym okresie został rozwinięty o kategorię opisową: młody dorosły - obejmujący osoby, które przekroczyły już dwudziesty rok życia, a które nie są jeszcze traktowane jako dorośli ${ }^{4}$.

cjalno-ekonomicznego status quo ante". Szerzej: C. Offe, Politische Legitimation durch Mehrheitsentscheidung?, w: B. Guggenberger, C. Offe, An der Grenzen der Mehrheitsdemokratie. Politik und Soziologie der Mehrheitsregel, Westdeutscher Verlag GmbH, Opladen 1984; za: B. Włodawiec, Claus Offe o politycznej legitymizacji poprzez decyzję większości, http://www.psychologia.net.pl/artykul.php?level=162, dostęp: 1.02.2009.

3 Por. Hebdige 1979; Bradley 1992; za: W. Wrzesień, Jednostka - rodzina - pokolenie. Studium relacji międzypokoleniowych, Poznań 2003.

4 Por. A. Kłoskowska 1987; Fatyga 1997; 1999; za: W. Wrzesień, Jednostka..., op. cit., s. 38 . 
Młodzież niejako ,przy okazji”, nabyła atrybut (jakim było wzmożone zainteresowanie), który do dziś ma swoje rozległe konsekwencje: ekonomiczne, społeczne, polityczne oraz edukacyjne. Mówiąc wprost, dziś nie da się zwyczajnie przejść obok młodych obojętnie. Gdyż stali się oni potencjalnym klientem nie tylko dla koncernów produkujących dobra i dostarczających usługi, dla polityków odwołujących się do nich jako elektoratu, ale także szkół - walczących o uczniów niemalże na zasadach rynkowych. Młodzi, stali się po prostu ważni dla świata. Stali się siła, którą wiele podmiotów stara się zaadoptować czy wręcz wykorzystać do swoich potrzeb.

W naszych analizach, pominiemy kwestie dotyczące kampanii marketingowych międzynarodowych koncernów; kampanii rekrutacyjnych prywatnych i niepublicznych szkół wyższych (choć pojawią się oczywiście wątki edukacyjne); a skupimy uwagę na politykach, którzy także z ogromną pieczołowitością, czasem wręcz desperacją zabiegają o uwagę i głosy młodych. W okresie kampanii wyborczych (i tuż przed jej rozpoczęciem), doniesień medialnych dotyczących tych aktywności jest aż nadto. Dotyczą one całej sceny politycznej, nie tylko w naszej ojczyźnie, ale także poza jej granicami.

Większość współczesnych młodych, wychowanych na grach wideo, nieustannie przemieszczających się, pogrążonych w wirtualnym świecie kontaktów, blogów i serwisów społecznościowych, i bardzo często stroniących od polityki, utożsamianej ze „sztywnością i nudą dorosłego świata" jest bardzo trudnym partnerem dla polityka ${ }^{5}$. Przyciąnnięcie ich uwagi - wzbudzenie zaciekawienia, jest jednym z najbardziej wymagających zadań współczesnych nadawców komunikatów. Widać to chociażby w mediach - a szczególnie w reklamach, kierowanych do młodych. Tym ostatnim, poświęca się mnóstwo czasu - inwestuje w ,relację”, uważając, że to oni są nośnikami trendów ${ }^{6}$. Wiedzą to także politycy.

„Zwyczajna” promocja, reklama czy marketing polityczny nie wystarczają by zaciekawić młodych dorosłych. Stąd też literatura odnotowuje już pojawienie się nowych kreatorów społeczno-politycznej rzeczywisto-

5 „Młodzi są zagubieni. Politycy też są zagubieni, bo nie umieją na te wyzwania [młodych] odpowiedzieć". Ibidem.

${ }^{6}$ Zob. m.in. Rozmowę K. Jaklewicz z R. Zydlem (wykładowcą z Instytutu Etnolologii i Antropologii Kulturowej UW). K. Jaklewicz, Konsumenci, generacja Y, „Wysokie Obcasy” dodatek do „Gazety Wyborczej”, 30 lipca 2011, s. 28-30. 
ści - tzw. story-spiners - czyli specjalistów od nowych zadań; realizowanych $\mathrm{w}$ zupełnie przewartościowanym otoczeniu polityki przyszłości, nazywanej przez niektórych autorów postpolity $\mathrm{kq}^{7}$. Aby jednak cele, postawione przez polityków mogły być zrealizowane skutecznie, a nie tylko na zasadzie politycznego epizodu; konieczne jest odpowiednie przygotowanie młodego audytorium. Niezbędne jest posiadanie przez nich przynajmniej minimalnych kompetencji poznawczych, pewnej dozy autorefleksji, a także czynnika, który nazwać można by nieco kolokwialnie: „sprzyjającą atmosferą" (czy też przyjaznym otoczeniem społeczno-politycznym). Ukształtowanie czy też wypracowanie powyższych, jest długotrwałym procesem realizowanym przez różne podmioty $i$ instytucje biorące udział w tzw. procesach socjalizacji politycznej ${ }^{8}$. Dopiero na końcu tej drogi, znajduje się cel - przejście od stanu biernej obserwacji lub wycofania, najpierw do zainteresowania, czy wreszcie faktycznego obywatelskiego uczestnictwa.

\section{Kapitał społeczny. Społeczno-instytucjonalne czynniki wykluczenia młodzieży}

Możemy wyróżnić dwa główne rodzaje czynników udziału młodzieży w życiu społeczno-politycznym: są to determinanty instytucjonalne i systemowe. Do pierwszej grupy, z pewnością zaliczyć możemy: rodzinę, szkołę, grupę rówieśniczą czy nawet różnego typu instytucje kultury. Drugą z nich, będą tworzyły: regulacje ustawowe, a więc porządek prawny, istnienie i dostępność organizacji o obywatelskim charakterze działania, społeczno-polityczna praktyka, jak również otwartość elit w danym reżi-

7 Per analogiam: modernizm - postmodernizm. Szerzej w: M. Karnowski, E. Mistewicz, Anatomia władzy, Warszawa 2010, s. 24 i n. Zob. także: M. Brylczak, Od propagandy do manipulacji. Ksztaltowanie wizerunku polityków w mediach tradycyjnych i nowoczesnych, w: Wartości w polityce. Między sprawnościa a normalnościa, red. J. Miluska, w druku.

8 P. Pawełczyk, definiuje ten proces następująco: „socjalizacja polityczna korzysta ze złożonej sieci kar i nagród. Celem jej stosowania jest przyswojenie przez jednostkę wiedzy o konsekwencji i zasadach gry politycznej, przyjęcie określonych postaw politycznych, podporządkowanie ogólnie przyjętym interpretacjom celów politycznych, zaakceptowanie zinstytucjonalizowanych zobowiązań wobec danego systemu politycznego oraz wzmocnienie przywiązania do niego. Za: P. Pawełczyk, Socjotechniczne aspekty gry politycznej, Poznań 2000, s. 88. 
mie politycznym. Naszą uwagę skupiać będziemy jednak przede wszystkim na roli szkoły - jako instytucji powołanej do kształcenia postaw obywatelskich.

$\mathrm{Na}$ początku, przyjrzymy się zjawisku wykluczenia. Z jednej strony, może być ono rozumiane jako swoista eliminacja jednostek z życia - ograniczenie ich działania, które charakteryzuje reżimy totalitarne. Z drugiej, dotyczyć może działalności opozycji w systemach demokratycznych - co jednak w najlepszym wypadku, kategoryzowane jest jako działania a-demokratyczne, a więc: sprzyjające powstawaniu „mono-władztwa”. To z kolei, jest jedną z przyczyn wycofywania się obywateli z aktywnego życia (społeczno-politycznego). Wykluczenie dotyczyć może różnych grup w społeczeństwie.

Jeśli chodzi o młodzież, opisany we wstępie swoisty stan euforycznego zwrotu ku młodym, nie jest obrazem pełnym. Istnieją bowiem również alternatywne diagnozy dotyczące miejsca - pozycji w strukturze społecznej, zajmowanych przez młodych dorosłych. Opisują one młodzież jako grupę nieobecną czy też wykluczoną z życia społeczno-politycznego. Mówi się o młodych jako jednostkach nieprzystosowanych czy wręcz wyalienowanych ${ }^{9}$. Wskazuje się na brak jasnych ram funkcjonowania - pewien stan zagubienia czy poczucie wyobcowania, co może w dużym stopniu zakłócać proces ich uczestnictwa w aktywnościach obywatelskich. Wykluczeniu może sprzyjać swoista sieć barier, na które natrafiaja na różnych etapach swojego dochodzenia do dorosłości. Poczynając od barier społeczno-demograficznych i związanych z tym tzw. syndromu nierównych szans; poprzez czynniki ekonomiczne (dostępności dóbr, możliwości dodatkowego kształcenia, zdobywania wiedzy), aż po systemowe ograniczenia możliwości realizacji (np. niedostosowanie systemu edukacji do zmieniających się potrzeb na rynku pracy) ${ }^{10}$.

W tym miejscu wydaje się konieczne wspomnienie pojęcia kapitału społecznego - autorstwa - P. Bourdieu (1970). Termin ten został później

9 Zob.: M. Seeman (1959, 1975); K. Kiciński 2001; K. Skarżyńska, K. Chmielewski (1993); A. Jakubik (1999); A. Jakubik, K. Piaskowska (2000); K. Kmiecik-Baran (1995); P. Piotrowski (2000); K. Korzeniowski (1991).

${ }^{10}$ Zjawisko „nadproducji” ekonomistów, specjalistów ds. marketing, socjologów; kosztem potrzebnych na rynku pracy inżynierów, informatyków, lekarzy. Por. „Raport o rozwoju spolecznym Polska 2007 - Edukacja dla pracy”. Rozmowa z prof. Urszula Sztanderska, http://www.skp_nansen.republika.pl/artykul_mk5.pdf, dostęp 27.06.2011. 
rozwinięty i spopularyzowany przez J. Colemana i R. Putnama $(1995)^{11}$. Można zaryzykować tezę, iż współcześnie jest on uznawany, za kluczową determinantę uczestnictwa $\mathrm{z}$ życiu społeczno-politycznym ${ }^{12}$. P. Bourdieu przeciwstawił sobie dwie grupy młodzieży, które różnią się rodzajem „zasobów”, tworzących i wpływających na rozwój ich kapitału społecznego ${ }^{13}$. Z jednej strony opisywał tych, dla których studia wyższe stanowią naturalną i oczywistą fazę drogi życiowej, zaplanowaną i wspieraną przez rodzinę. Oraz drugą grupę, do której należą dzieci z rodzin robotniczych i wiejskich, stających wobec przeróżnych barier i przeszkód (nieraz nie do pokonania), na drodze do wyższej edukacji. Te dwa rodzaje środowisk, w sposób istotny determinują jakość posiadanego przez jednostki kapitału społecznego ${ }^{14}$. Choć według M. Ogryzko-Wiewiórkowskiej, kluczowe znaczenie ma również kwestia tzw. „motywacji rozwojowych” $\mathrm{u}$ młodych $\mathrm{z}$ tych środowisk ${ }^{15}$. Zdaniem tej autorki, nawet najbardziej ambitne programy rozwojowe ${ }^{16}$ (np. komputer $\mathrm{z}$ dostępem do Internetu w każdej szkole) w połączeniu z nieograniczonymi nakładami finansowymi, ale bez jednoznacznej deklaracji współudziału ze strony młodych, pozostaną jedynie ,zapisem na papierze”, a podziały które miały likwido-

11 Zob.: R. Putnam, R. Leonardi, R. Y Nanetti, Demokracja w działaniu: tradycje obywatelskie we wspótczesnych Włoszech, Znak, Kraków, Fundacja im. Stefana Batorego, Warszawa 1995, s. 258.

12 Zob. koncepcje teoretyków partycypacji politycznej (Coleman 1988; Fukujama 1995, 2003; Putnam 1995; Verba i in. 1995). Za K. Skarżyńska, Człowiek a polityka. Zarys psychologii politycznej, Scholar 2005, s. 158-159.

13 Za: Encyklopedia pedagogiczna, op. cit., s. 327, hasło: młodzież.

${ }^{14}$ Ibidem. Zob. także: rozmowa Lidii Ostałowskiej o młodzieży, z B. Fatyga, Młodzież odtaczona, „Gazeta Wyborcza”, nr 202, wyd. 30.08.2003, „Gazeta Świąteczna”, s. 12. „Co czwarty absolwent szkoły wiejskiej nie rozumie prostych tekstów. Połowa młodzieży wiejskiej deklaruje, że chce skończyć studia, ale $60 \%$ poprzestaje na podstawówce. Jednocześnie $67 \%$ młodych Polaków uważa, że stosunki pomiędzy politykami a zwykłymi obywatelami układają się źle i bardzo źle". Poza konfliktem pomiędzy zamożnymi i bogatymi oraz pomiędzy inteligencją a robotnikami to główne pole konfliktów społecznych. Zdaniem prof. Fatygi: jedynie szkoła jawi się jako najlepszy instrument do ich przezwyciężenia. „Mądry system edukacyjny jest bowiem ścieżką do dobrobytu, stabilizacji”.

${ }_{15}$ Por. M. Ogryzko-Wiewiórkowska, Świat dla młodych u progu nowego wieku, w: Młodzież w kontekście formowania się nowoczesnych spoleczeństw, red. W. Wawro, KUL 2004 s. 51.

${ }^{16}$ M.in. Programy edukacyjne podnoszące umiejętności młodzieży z terenów wiejskich. Wspierany przez UE w ramach Programu Kapitał Ludzki, Narodowa Strategia Spójności. 
wać, nie znikną. Opisane powyżej „różnice kapitałów” mogą być jedną z przyczyn powstawania tzw. syndromu niedopasowania, poczucia wykluczenia czy odrzucenia. Te ostatnie moga być poddawane analizie „przedmiotowo" - młodzież zostaje odrzucona przez system; lub „podmiotowo" - młodzież wycofuje się, odrzuca. Jeśli chodzi o pierwsze ujęcie - ciekawą diagnozę odnajdujemy w teorii ,porzuconej generacji”.

Termin ten, wprowadził do nauk społecznych H. Giroux w roku $2003^{17}$. W swoim dziele: The abandoned generation. Democracy beyond the culture of fear ${ }^{18}$, Giroux mówi tak: ,zbyt łatwo, oskarża się młodzież o wycofanie, polityczne uśpienie i nadmierny konsumpcjonizm - nie proponując jej nic lub prawie nic, czym mogła by naprawdę żyć. A wręcz przeciwnie, narzuca się na nich zbyt duże obciążenie - przede wszystkim odpowiedzialnością za własny los"19. Główni winowajcy wg H. Girouxa, to przede wszystkim osoby odpowiedzialne za edukację, [...], czy sprawy związane z rynkiem pracy. To bowiem niedostosowanie proponowanego wykształcenia do potrzeb rynku, strach przed bezdomnością i w końcu bezrobociem, są najczęściej wymienianymi dziedzinami niepewności - ryzyka. Owa niepewność ${ }^{20}$ jest przyczyną narastającej frustracji, a ta z kolei rozładowywana jest najczęściej w sposób, który zahacza o nieprzestrzeganie, a nawet jawny konflikt z prawem. Odpowiedzią państwa na ten stan, jest wzmożona kontrola - system kar i zakazów, zamiast rzeczowej propozycji dla młodych ${ }^{21}$. Ów brak poczucia stabilności, może leżeć u podstaw decyzji niektórych z nich, o świadomym wycofaniu się

17 H. A. Giroux, The a abordoned generation. Democracy beyond the culture of fear, New York 2003 - książka inspirowana wydarzeniami 11 września $2001 \mathrm{r}$.

18 Por. http://www.freechild.org/abandoned.htm, dostęp 1.03.2009.

19 Por. Obciążenia psychiczne młodych wg koncepcji ,społeczeństwa ryzyka" U. Becka (2002) za: K. Szafraniec, Polska młodzież: między apatia, partycypacja a buntem, w: A. Kojder, Jedna Polska?, WAM, Kraków 2006, s. 209.

20 Poczucie młodzieży, że otaczający świat jest pełen niebezpieczeństw; poczucie niepewności i zagrożenia zostało także potwierdzone w badaniach studentów polskich - zrealizowanych pod kierownictwem K. Skarżyńskiej (2009). Więcej o konsekwencjach m.in. w: K. Skarżyńska, Świat to dżungla, http://wyborcza.pl/1,75515,9970435,Swiat_to_dzungla.html, dostęp 22.07.2011.

${ }^{21}$ „Młodzież sięga więc po inne sposoby, mające skompensować jej różnice i realne poczucie krzywdy społecznej, przekraczając często normy społeczne i prawne w poczuciu zagrożenia marginalizacją". Za: B. Gallas, Pokolenie chaosu i nadziei. Socjalizacja w warunkach zmiany społecznej, w: Młodzież a dorośli. Napięcia między socjalizacja a wychowaniem, red. R. Kwiecińska, M. Szymański, Kraków 2001 s. 173 . 
(czy wykluczeniu) z aktywności w życiu publicznym. Aby temu przeciwdziałać, konieczne jest wdrożenie kompleksowego systemu edukacji obywatelskiej.

Jedną z czołowych instytucji państwa, której misją powinno być właściwe ukształtowanie swoich obywateli, jest szkoła. W niej to, już od najwcześniejszych lat - w ramach tzw. socjalizacji pierwotnej - następować powinien proces obywatelskiego wychowania.

\section{Szkoła demokracji}

Szkoła ma swoje stałe miejsce w systemie kształtującym człowieka, czy w węższym ujęciu: obywatela. Szkołę odnajdujemy w pierwszej grupie, wymienionych przez L. Sobkowiaka $(1996)^{22}$, triadzie czynników socjalizacyjnych: systemowych, środowiskowych i osobowościowych. Zdaniem tego autora, właśnie system edukacji (także obywatelskiej), obok państwa i instytucji partyjnych, będzie oddziaływaniem pierwotnym - jako że pozostałe będą oddziaływać w późniejszych okresach życia jednostki.

Podkreślenie ważkiej roli szkoły, jako instytucji edukacyjnej, znaleźć możemy także u wielu innych autorów. M.in. w książce M. Ossowskiej (1946), Wzór obywatela demokratycznego państwa ${ }^{23}$, natrafiamy na następujący postulat: „stworzyć takie warunki, aby jak największa liczba obywateli była zainteresowana i przejęta losami społeczeństwa jako całości”24. Autorka pisała również o pewnych niedoskonałościach w procesie, który nazywała uspołecznieniem: „Budzenie i pielęgnowanie tego rodzaju zainteresowań, zaniedbywane dotychczas w naszym wychowaniu, należy do bardzo ważnych zadań wychowawcy w ustroju demokratycznym”. I dalej: „czyż trzeba kogo przekonywać, że młodzież, która niebawem będzie, chociażby tylko przez głosowanie, brać czynny udział w kierowaniu swoim krajem, winna wiedzieć, [jak ważne jest] intereso-

22 Por. L. Sobkowiak, Świadomość i socjalizacja polityczna. Anatomia socjalizacji politycznej, w: Studia z teorii polityki, red. A. W. Jabłoński, L. Sobkowiak, t. I, s. 146 i n.

23 M. Ossowska, Wzór obywatela w ustroju demokratycznym, Zarząd Główny Towarzystwa Uniwersytetu Robotniczego, Warszawa 1946, s. 5-20.

24 Ibidem. Za: B. Gołębiowski, Edukacja polityczna - kultura polityczna, „Realia”, nr 5, październik 2009, http://realia.com.pl/dzial_8/artykul_22.html, dostęp 29.11.2009. 
wanie się zagadnieniami społecznymi i pewien zasób kompetencji w tej dziedzinie?"25.

Kolejnym autorem wpisującym się w powyższe, jest choćby P. Sztompka (2003), który w swoim Dekalogu obywatela ${ }^{26}$ na pierwszym miejscu wymienia konieczność ,aktywnego wspierania oddolnego zrywu edukacyjnego. Przekonuje on do podjęcia nie tylko deklaratywnej, ale i autentycznej polityki proedukacyjnej i pronaukowej”. W tym działaniu, upatruje autor największej „stopy zwrotu” (odwołując się do teorii kapitału społecznego Bourdieau). Kapitał ten jest niezbędnym fundamentem i budulcem [demokratycznej] zmiany ustrojowej. To właśnie w ludziach młodych, upatruje cytowany badacz nadziei. Dzięki lepszemu wykształceniu, będą oni mogli tworzyć profesjonalne zasoby ludzkie, niezbędne do przeprowadzania mądrych $\operatorname{zmian}^{27}$.

Podążając tym tropem, można zapytać czy kierowany do młodych ludzi przekaz (którego nadawcą jest instytucja edukacyjna), który ma za zadanie m.in. kształtowanie możliwości poznania politycznego - jest skuteczny? Czy sposób odzwierciedlenia żądań, czy też „reguł gry politycznej” jest na tyle wyczerpujący i czytelny, że młody człowiek wejdzie z nim w interakcję i skorzysta z możliwość zwrotnej odpowiedzi, wyrażonej przez uczestnictwo w życiu politycznym? Odpowiedź na powyższe pytania nie jest prosta. Mimo wyrażanego często przez młodych „oporu”, wobec opinii formułowanych przez pedagogów, nie sposób odmówić racji twierdzeniu, że szkoły mogą mieć swój niebagatelny wkład w kształtowanie świadomości. Mogą to czynić choćby poprzez przekazywanie wiedzy o niepisanych regułach gry politycznej, wyrażonych $\mathrm{np}$. w politycznych tradycjach danego społeczeństwa ${ }^{28}$. Ten pogląd znajduje poparcie już

25 M. Ossowska (1946), por.: Centrum Edukacji Obywatelskiej - serwis internetowy dostępny pod adresem: http://www.ceo.org.pl/portal/epio_dokument?do$\mathrm{cId}=35419$, dostęp 24.02.2010. Potwierdzającą powyższe opinię odnajdujemy także u A. Dziubińskiej: „Wszak niemożliwe jest prawidłowe funkcjonowanie demokracji bez civil socjety, a takowe stanowią świadomi, zaangażowani w jego rozwój obywatele”. Za: A. Dziubińska, Kształtowanie świadomości obywatelskiej na przykładzie wspótpracy politologicznych kót naukowych z nauczycielami WOSu $i$ historii, w: Szkice politologiczne - publikacja pokonferencyjna I Przegladowej Konferencji Politologicznych Kół Naukowych, „Politeja”, Kraków 2008, s. 21.

${ }^{26}$ Tytuł zaczerpnięty z artykułu w GW, tekst pochodzi z konferencji wygłoszonej podczas debaty zorganizowanej przez Prezydenta RP 30 października 2003 r., w: „Gazeta Wyborcza”, nr 8, 10 stycznia 2004, s. 17.

27 Por. P. Sztompka, Dekalog obywatela, ibidem, s. 17.

28 Por.: P. Pawełczyk, Socjotechniczne aspekty gry politycznej, Poznań 2000, s. 92. 
w koncepcji D. Eastona na początku lat 70-tych ubiegłego wieku. Wskazywał on na ważność treści zawartych w mitach i doktrynach politycznych przekazywanych następnemu pokoleniu - wg niego, nadają one określonej interpretacji celom i normom politycznym.

Podobnie mocno brzmiący głos za wychowaniem demokratycznym w szkołach, odnajdujemy w badaniach K. Szafraniec (2006). Pisze ona wyraźnie: ,znaczenia szkoły w kształceniu obywatelskim w żadnym razie nie wolno lekceważyć. Tak wychowanie rodzinne, jak zwłaszcza szkoła [...] dysponują potężną siłą: możliwością oddziaływania bezpośrednio na serca i umysły młodych ludzi" ${ }^{29}$. Autorka zastrzega jednak, że należy odrzucić działania doraźne, i skupić się na wypracowaniu i wdrożeniu w życie długofalowego, zabezpieczonego w środki finansowe i opartego na dobrym prawie, programu edukacji obywatelskiej. Tylko takie działania zapewnią skuteczne przekazywanie wzorców, profesjonalnej wiedzy obywatelskiej, budujących demokratyczną aktywność. A zatem, aby mądrze działać i skutecznie przekazywać dobre wzorce - zadbać należy najpierw o właściwe rozumienie zarówno demokracji jako systemu, jak i swoich praw i obowiązków, a także katalogu możliwości oraz zakresu działania ${ }^{30}$.

A jak to wygląda w polskich szkołach? Po pierwsze należy zauważyć, iż w wielu miejscach mamy do czynienia z pewnym rozdźwiękiem pomiędzy misją szkoły w sferze zamierzeń a ich realizacją. Lektura oficjalnych dokumentów - jak choćby rozporządzenia Ministra Edukacji Narodowej z dnia 23 grudnia 2008 r., a zwłaszcza tej jego części, która poświęcona jest celom i treściom kształcenia młodzieży w wiedzy o społeczeństwie ${ }^{31}$, może być potraktowana, jako swoiste stawianie kamieni milowych w procesie edukacji obywatelskiej. Autorzy tego dokumentu, starali się nakre-

29 Por. K. Szafraniec, Polska młodzież: między apatia, partycypacja a buntem, w: A. Kojder, Jedna Polska?, WAM, Kraków 2006, s. 232.

30 W tym miejscu warto wspomnieć o tzw. wskaźniku scholaryzacji, który jest miarą zaspokojenia aspiracji edukacyjnych jednostki. Dla badanych jednostek (w przedziale wieku 15-18 lat), w latach 1990-1992 wynosił 83,5\%, w 1996-1998 wzrósł do poziomu 87\%; analogicznie dla przedziału wiekowego 19-24 lata wynosił on 21\% i 34\% - za: B. Kołaczek, Aspiracje edukacyjne i możliwości ich realizacji, w: Pokolenie wygranych? Dzieci i młodzież w procesie transformacji społeczno-gospodarczej i politycznej Polski, red. J. Sztumski, Katowice 2001, s. 98-99.

$31 \mathrm{~W}$ sprawie podstawy programowej wychowania przedszkolnego oraz kształcenia ogólnego w poszczególnych typach szkół patrz: Dz. U. z dn. 15 stycznia 2009, $\mathrm{Nr} 4$, poz. 17 , s. 346-353. 
ślić ambitny plan, którego realizacja ma na celu, skuteczną i powtarzalną reprodukcję struktury obywatelskiej (społeczno-politycznej) ${ }^{32}$. W części dotyczącej celów kształcenia, znajdujemy m.in. następujące zapisy: „uczeń znajduje i wykorzystuje informacje na temat życia publicznego; wyraża własne zdanie i uzasadnia je; jest otwarty na odmienne poglądy". I dalej: „uczeń rozumie demokratyczne zasady i procedury i stosuje je w życiu szkoły oraz innych społeczności; rozpoznaje przypadki łamania norm demokratycznych i ocenia ich konsekwencje; wyjaśnia znaczenie indywidualnej i zbiorowej aktywności obywateli [...] wykorzystuje swoją wiedzę o zasadach demokracji i ustroju Polski do rozumienia i oceny wydarzeń życia publicznego".

W wymaganiach szczegółowych treści nauczania, odnajdujemy m.in.: „wyjaśnia jak człowiek staje się obywatelem [...] podaje przykłady uprawnień i obowiązków wynikających z posiadania polskiego obywatelstwa; przedstawia argumenty przemawiające za udziałem w wyborach lokalnych, krajowych i europejskich; wymienia zasady demokratycznych wyborów i stosuje je w głosowaniu w szkole; wskazuje czym powinien kierować się obywatel, podejmując decyzje wyborcze; krytycznie analizuje ulotki, hasła i spoty wyborcze"33. Jak wspomniano, to tylko niektóre zapisy tego dokumentu, wskazujące kształconym i kształcącym, sfery wymagające refleksji, poznania i wdrożenia w życie. Stanowią one drogowskazy w procesie edukacji obywatelskiej, a jednocześnie wytyczne, które powinny zostać wypełnione w pracy nauczyciela z uczniem. Dokonując oceny jedynie warstwy semantycznej (nie formułując wniosków o wyczerpywalności wymienionych kategorii), możemy powiedzieć, że z punktu widzenia państwa, praktyczne wypełnienie treści zawartych w tym „modelu idealnym” jest ze wszech miar pożądane. Jak to wygląda w rzeczywistości? Zapewne różnych odpowiedzi na to pytanie, udzieliłaby zarówno jedna (uczeń), jak druga strona (nauczyciel). Nie jest możliwe rozstrzygnięcie tej kwestii w ramach niniejszej analizy. Jest natomiast wskazane, aby znaleźć ew. przyczyny niepowodzenia w realizacji jednego, czy drugiego obszaru ${ }^{34}$.

32 Por. teoria kapitału społecznego Bourdieu.

33 Ibidem.

34 Jeszcze w roku 2003, B. Fatyga na postawie wyników wieloletnich badań, napisze: „nauczyciele to jedna z najbardziej nielubianych przez młodzież grup dorosłych. To jej zdaniem jedna $\mathrm{z}$ pra-przyczyn nieobecności młodych w życiu publicznym. Przytacza dane porównawcze (badania K. Koseły), że w Polsce udział 
Kolejnym, ważnym i wymagającym przywołania dokumentem, który powstał w roku 2003 z inicjatywy biura młodzieży z MENiS (Ministerstwa Edukacji Narodowej i Sportu), pod kierunkiem B. Fatygi, jest „Strategia dla Młodzieży na lata 2003-2012". Raport ekspertów, którego podstawę stanowi tzw. Biała Księga Komisji Europejskiej, określa m.in. priorytety i zadania wynikające z dokumentów akcesyjnych. Poza diagnozą sytuacji młodych ludzi w Polsce (m.in. problemów materialnych, bytowych i edukacyjnych), jest to zbiór propozycji współpracy młodych Europejczyków, tak aby mogli się oni stawać współodpowiedzialnymi za podejmowanie decyzji - od szczebla lokalnego po centralny. Z zebranych danych wynika, iż aspiracje edukacyjne młodych są ogromne, jednak polski system edukacji sprzyja segregacji - rośnie bowiem nierówność w dostępie do wykształcenia. Zauważalne są różnice kapitału społecznego młodych ze środowisk miejskich i wiejskich. Doświadczamy komercjalizacji oświaty. Autorzy raportu, w obliczu stwierdzonego braku narodowego systemu zbierania informacji o młodzieży (w odróżnieniu od europejskich sąsiadów); sformułowali zalecenie jego jak najszybszego wprowadzenia. Tylko bowiem jego skuteczne wykorzystanie, pozwoli prowadzić odpowiedzialna polityke. Postulat ten znalazł odzwierciedlanie w otwierającym „Strategię”, motto: „Aby skutecznie działać, trzeba korzystać z informacji. Aby informację wykorzystywać - trzeba ją mieć" ${ }^{\prime 35}$. Wydaje się, że konsekwentna realizacja tak postawionych zadań, mających swoje uzasadnienie we wnikliwej (choć bolesnej - bo obnażającej niedociagnięcia) analizie, zaczęła przynosić pierwsze efekty.

Niektóre z nich, odnajdujemy choćby w pracy A. Zielińskiej (2008) - Nastoletni uczniowie o demokracji. Uwarunkowania społeczno-demograficzne i edukacyjne pogląów młodzieży. Autorka już we wstępie pisze, tak: „o tym jaka będzie demokracja w naszym kraju, czy spełni pokładane w niej nadzieje, czy okaże się stabilną formą organizacji życia

w wyborach do samorządu szkolnego deklaruje zaledwie 9\% uczniów. Dla porównania w Norwegii ponad połowa (ponad 50\%). Ponadto, polscy absolwenci, aż w 75\% uważają iż szkoła średnia nie przygotowuje do aktywności politycznej, w $66 \%$ do aktywności publicznej, a w 56\% do życia w Unii Europejskiej. Stoi to w znacznym kontraście wobec nazbyt optymistycznych danych o pracy własnej zbieranych przez nauczycieli. Więcej: Rozmowa L. Ostałowskiej z B. Fatygą, Młodzież odłaczona, op. cit., s. 12 i n.

35 Ibidem. Zob. także: projekt aktualizacji strategii państwa dla młodzieży na lata 2003-2012, dostępny na stronie Ministerstwa Edukacji Narodowej: http://bip.men.gov.pl/ men_bip/akty_projekty/projekt_strategii_ala_mlodziezy_2003-12.pdf, dostęp 1.07.2011. 
społecznego, czy zakorzeni się głęboko w mentalności społecznej, zadecyduje stosunek do demokracji młodych ludzi”"36. Praca ta jest szczegółowym zbiorem wyników badań, nie tylko na temat stanu wiedzy i postaw wobec demokracji polskich nastolatków, ale także ich europejskich koleżanek i kolegów ${ }^{37}$. Ale jest też zarazem próbą diagnozy i opisu tych, którzy powołani są do „niesienia kaganka oświaty”38. Otóż, praktycznie bezwyjątkowo polska (i europejska) młodzież uznaje za ważne dla demokracji czynniki powszechnie uznane za jej wyznaczniki (markery), są to m.in.: funkcjonowanie wolności wypowiedzi, instytucji wolnych wyborów oraz stowarzyszeń i organizacji, do których można wstępować na zasadzie dobrowolności. Badana młodzież, najsilniej odrzucała - jako sprzeczne z demokracją - wpływanie przez bogatych na rząd, nepotyzm, brak niezależności sądów, zakaz krytyki rządzących oraz istnienie prasowego monopolu. Przynajmniej częściowe potwierdzenie, znalazły też założenia przywołanej na początku teorii kapitału społecznego. Autorce udało się dowieść, iż w opinii badanych uczniów, szkoła to rzeczywiste miejsce, w którym można nauczyć się demokracji w praktyce. O jakości socjalizacji szkolnej, decyduje przede wszystkim siła przeświadczenia uczniów, iż tylko przez wspólne działanie mogą oni zmienić sytuację w swojej szkole ${ }^{39}$.

Z satysfakcją, odnotować możemy istnienie także ogólnoeuropejskich inicjatyw, które w sposób twórczy chcą przeciwdziałać wykluczeniu obywatelskiemu młodzieży już od bardzo wczesnych lat. Wspomnieć można

36 Zob: A. Zielińska, Nastoletni uczniowie o demokracji. Uwarunkowania społeczno-demograficzne i edukacyjne pogladów młodzieży, Wydawnictwo UW 2008, s. 7-8.

37 Badania przeprowadzono w ramach Civic Education Study (w Polsce: A. Frączek, A. Wiłkomirska, R. Dolata, A. Zielińska) oraz krajach tzw. starej i nowej Unii, a także Norwegii, Szwajcarii, Rosji i USA. Wśród krajów naszego regionu były m.in. Czechy, Słowacja, Niemcy, Łotwa, Litwa i Estonia.

38 W cytowanej już pracy A. Zielińskiej - cały rozdział poświęcony jest także wychowawcom, nauczycielom historii, nauk wiedzy o społeczeństwie i języka polskiego, jako grupy mających największy zdaniem autorki wpływ na kształtowanie (formowanie) postaw obywatelskich wśród młodych. Zob. A. Zielińska, op. cit., s. 205-252. Autorka dowodzi, iż większość z nich [nauczycieli] cechuje tzw. optymizm pedagogiczny - wierzą oni w możliwości szkoły w zakresie edukacji obywatelskiej. Jest jednak dość liczna grupa tych, którzy czują się zagubieni w problemach współczesności - nie wiedząc jakie są w tym zakresie oczekiwania społeczne, co jest najważniejsze, a co drugorzędne w przygotowaniu nastolatków do demokracji i życia w społeczeństwie obywatelskim. Ibidem, s. 249.

39 Ibisem, s. 106. 
choćby o programie URBACT, który jest europejskim programem wymiany wiedzy i doświadczeń promującym zrównoważony rozwój miejski ${ }^{40 "}$. „Młodzież - od wykluczenia do włączenia”, to jedna z sieci tematycznych programu, która ma za zadanie rozwijanie strategii, jak wpływać na zmianę sytuacji młodzieży. Sieć prowadzona jest przez szwedzkie Malmö, a jednym z miast eksperckich była też polska Łomża. Jednym z dwóch wartych przywołania postulatów (które były potem realizowane w ramach projektu) było: wzmacnianie relacji społecznych, co wpływa korzystnie na proces uczenia się, a ten z kolei znajduje przełożenie na doskonalenie pewności siebie, zaufania oraz komunikacji w relacji nauczyciel-młody człowiek ${ }^{41}$. Po wtóre, zwrócono szczególną uwagę na kwestię weryfikacji struktury systemu szkolnictwa. Zmiany te, powinny zdaniem autorów raportu sięgać sedna strukturalnych przyczyn wykluczenia - tak, aby zapobiegać utracie zaufania i rezygnacji wśród uczniów. Ponadto, należy przeprowadzić je w ten sposób, by umożliwić szkołom kapitalizację potencjału młodzieży. Poniżej przykład projektu „Głos młodzieży” zrealizowanego w roku 2005 w Helsinkach. Celem projektu była poprawa szkolnej demokracji.

„Projekt zainicjowano w wyniku istniejącego przeświadczenia, iż młodzież nie doświadcza wystarczającej liczby szans, aby wpływać na bieg własnego życia. Brak takiego wpływu staje się głównym powodem, a także i skutkiem wyłączenia społecznego. $Z$ tej przyczyny, celem projektu jest promowanie oraz zachęcanie młodych ludzi do uczestniczenia w podejmowaniu decyzji. Jak zapisano w Prawach Dziecka Konwencji Narodów Zjednoczonych, szkoły i ośrodki młodzieżowe zobowiązane są do praktycznego stosowania mechanizmów demokratycznych, aby umożliwić młodym ludziom poznanie sposobu ich działania. Sedno projektu stanowi możliwość zaangażowania młodzieży na poziomie klas szkolnych. Zastosowano tu metodę rozwiązywania problemów o nazwie „Warsztaty przyszłości”. Powstałe pomysły i sugestie są przekazywane dalej przez wybranych uczniów. Ostatecznie, decyzje o finansowaniu podejmowane są na spotkaniu z burmistrzem. W roku 2005 w projekcie wzięło udział 140 szkół, w tym 40000 uczniów w wieku 7-18 lat" ${ }^{\text {"42. }}$.

40 Więcej informacji na http://www.urbact.pl/oprogramie.html.

41 Szerzej w raporcie dostępnym na http://www.lomza.pl/bip//zalaczniki/art/ 061124085121.pdf.

42 Źródło: Młodzież od wykluczenia do właczenia - wytyczne do działań, s. 10, http://www.lomza.pl/bip//zalaczniki/art/061124085121.pdf, dostęp: 27.06.2011. 


\section{E-demokracja - postnowoczesne kompetencje młodzieży, jako uczestnika życia politycznego}

Na koniec, warto również wspomnieć o jeszcze jednym - niezbędnym dziś - zbiorze kompetencji, jakim powinna dysponować jednostka. We współczesnym świecie, opartym na mediach i przekazie elektronicznym, nie sposób nie zatrzymać się na ważnym, choć nierealizowanym zadaniu szkoły, jakim jest przygotowanie do życia w obszarze kompetencji medialnych. Pisze o tym choćby W. Strykowski (2004). Zdaniem tego autora „ludzie, którzy ich nie zdobędą, znajdą się na straconej pozycji - staną się analfabetami medialnymi”43. T. Goban-Klas także apeluje: „powszechna edukacja medialna - od uczniów do polityków - jest zatem niezbędna"44. W. Strykowski cytuje też hasło autorstwa prof. R. Tadeusiewicza - pioniera wprowadzania technik teleinformatycznych w życie uczelni i studentów: „bądź Kolumbem cyberprzestrzeni”. Nawiązuje ono do surfowania po zasobach Internetu (per analogiam żeglowania po wezbranym morzu), gdzie potrzebny jest nie tylko właściwy sprzęt, ale także wiedza. Jest ona niezbędna dla uniknięcia związanych z poruszaniem się w sieci niebezpieczeństw, ale także - a może przede wszystkim - w procesie odnajdywania nowych obszarów (zastosowań mediów).

I właśnie w umysłach młodych - aktywnych - internautów (choć nieco starszych niż przywołani powyżej 13-19-latkowie), narodziła się bardzo ciekawa inicjatywa, wykorzystująca możliwości jakie daje sieć, do unowocześnienia i uatrakcyjnienia partycypacji obywatelskiej - zwłaszcza wśród młodzieży. Jest to projekt Demokracja 2.0 - pomysł młodych ludzi, którzy po 20 latach funkcjonowania demokracji w Polsce, dostrzegając niedoskonałości polskiego państwa i jego instytucji, postanowili wziąć sprawy w swoje ręce. Będący w 2004 roku w większości studentami - młodzi zapaleńcy, zapragnęli mieć realny wpływ na kształtowanie ładu prawnego (a tym samym i porządku demokratycznego) w naszej młodej demokracji. Postawili następującą diagnozę: „Polacy korzystają z internetu [a] Państwo polskie nie chce, lub nie umie tego robić" ${ }^{45}$. Sami

$43 \mathrm{Za}$ : Kompetencje medialne społeczeństwa wiedzy, red. W. Strykowski, W. Skrzydlewski, Poznań 2004, s. 7.

${ }^{44} \mathrm{Za}$ : T. Goban-Klas, Media i komunikowanie masowe. Teorie $i$ analizy prasy, radia, telewizji i Internetu, Warszawa 2006, s. 307.

45 Za: Manifest. Zespól projektu Demokracja 2.0 - http://www.demokracja20.pl/manifest/, dostęp: 2.02.2010. Podobną diagnozę odnajdujemy także u D. Batorskiego, 
uzbrojeni w niezbędną wiedzę, jak wykorzystać to nowe medium do budowania demokracji uczestniczącej, rozpoczęli realizację swoich idei. W Manifeście, nie odnajdujemy odwołania wprost to postulatów L. Porębskiego (2001), ale można założyć, iż przynajmniej w sposób nieformalny jest on ich sprzymierzeńcem, a może nawet inspiratorem. Jest on bowiem zdeklarowanym zwolennikiem edukowania obywateli w dziedzinie IT, opowiada się także za ustanowieniem społeczności lokalnej, jako bazy do podejmowanych działań w ramach sieci. To strukturalne uporządkowanie, ma być z kolei gwarantem właściwego wykorzystania technologii jako przedłużenia działań obywatelskich, prowadzących do upowszechnienia elektronicznych wyborów ${ }^{46}$.

Nasi Demokraci 2.0, również rozpoczęli działania ,metodą małych kroków". Na początek, poddają analizie i ocenie ścieżkę legislacyjną niektórych aktów prawnych - śledzą losy wybranych projektów ustaw ${ }^{47}$. Docelowo chcą mieć możliwość nie tylko biernego komentowania procedowania zapisów ustawowych, ale także realnego ich kształtowania (ew. obywatelskiego interpelowania ${ }^{48}$ ). Ma temu służyć uchwalenie ustawy o podpisie elektronicznym, dzięki czemu możliwa jest wiarygodna weryfikację obywatela i tym samym jego faktyczne uczestnictwo w życiu instytucji państwa, realizowane za pośrednictwem: komputera podłączonego do Internetu, odpowiedniej aplikacji i nośnika danych, który jest

który pisze: „Upowszechnienie technologii komunikacyjno-informacyjnych odbywa się przede wszystkim dzięki działaniom podejmowanym na własną rękę przez obywateli, państwo robi w tej dziedzinie niewiele i ciagle pozostaje w tyle”. Za: D. Batorski, Podstawy społeczeństwa informacyjnego w Polsce, w: Wymiary życia społecznego. Polska na przetomie XX i XXI wieku, red. M. Marody, Warszawa 2007, s. 490.

46 Za: L. Porębski, Elektroniczne oblicze polityki. Demokracja, państwo, instytucje polityczne w okresie rewolucji informacyjnej, Kraków 2001, s. 31. ring/.

${ }^{7}$ Lista aktualnych projektów na stronie: http://www.demokracja20.pl/monito-

${ }^{48}$ Nie jest to stricte kategoria politologiczna. Istnieje interpelacja poselska, czyli rodzaj funkcji kontrolnej, gdy poseł lub Marszałek Sejmu może skierować do Prezesa Rady Ministrów lub konkretnego ministra pytanie, na które musi zostać udzielona odpowiedź, dodatkowo może też odbyć się debata parlamentarna. W znaczeniu powyższym - per analogiam interpelacji poselskiej - interpelacja obywatelska byłaby np. zapytaniem obywatela lub grupy obywateli skierowanym do posła lub radnego w konkretnej sprawie. Przykład takiego zapytania o sprawy lokalne, na stronie internetowej podwarszawskiej Gminy Marki - obywatele pytają o funkcjonowanie komunikacji gminnej - zob.: http://www.marki.net.pl/interpelacja-obywatelska-1090, dostęp 8.11.2008. 
czymś w rodzaju elektronicznego dowodu osobistego. Tak wyposażony obywatel zyskuje znacznie większe możliwości działania - choćby poprzez „skurczenie się odległości czaso-przestrzennych” pomiędzy jednostkami oraz kolejnymi wydarzeniami. Jak czytamy w przywołanym już Manifescie: „Konstytucja Rzeczpospolitej Polskiej przewiduje w artykule 118 prawo do Obywatelskiej Inicjatywy Ustawodawczej. Formalny warunek zebrania 100000 podpisów pod każdą inicjatywą, stawia wysoką poprzeczkę. Za każdą inicjatywą musi stać organizacja i potężne zasoby [...] Jeśli wprowadzone zostaną biometryczne dowody osobiste i podpis elektroniczny stanie się masowo dostępny, droga do Demokracji 2.0 może stanąć otworem. Dzięki udostępnieniu możliwości zbierania głosów poparcia pod inicjatywami ustawodawczymi przez internet, zbudujemy prawdziwą czwartą władzę - dostępną dla wszystkich. Naszym celem jest budowa Ośrodka Obywatelskiej Inicjatywy Ustawodawczej internetowej instytucji, w której każdy obywatel i organizacja korzystając z wygodnych narzędzi przeprowadzi swoją inicjatywę ustawodawczą"49.

To bardzo odważne i nowatorskie dzieło - z pewnością odniesie sukces. Co prawda tego typu pomysł nie jest nowy. Dziesięć lat wcześniej - w 1994 roku - w amerykańskim stanie Minnesota złożony został projekt E-Demokracji. Była to konsekwencja udanych prób tworzenia lokalnych sieci obywatelskich, które ułatwiając dostęp do publicznych informacji, tym samym promowały zaangażowanie obywateli w życie społeczno-polityczne. Projekty przeprowadzono z sukcesem w trzech stanach: Seattle (Community Network), Cleveland (Freenet) oraz Kalifornii (PEN - Public Electronic Network). Tego typu przedsięwzięcia miały swoje odpowiedniki także w Europie, gdzie w stolicy Holandii powstało tzw. Cyfrowe Miasto ${ }^{50}$, a we włoskiej Bolonii program Iperbole ${ }^{51}$. Jak pisze D. Kotowicz (2006), dzięki ułatwieniu możliwości pionowej wymiany informacji i usprawnieniu poziomej komunikacji pomiędzy uczestnikami sieci, spowodowano, że „obywatele poczuli się bardziej zmotywowani do udziału w sprawach publicznych, czego implikacje stanowiło wzmocnienie lokalnej demokracji ${ }^{\text {"52 }}$. Badanie nad związkiem pomiędzy korzysta-

49 Manifest. Zespół projektu Demokracja 2.0 - http://www.demokracja20.pl/manifest/, dostęp 2.02.2010.

50 http://squat.net.ascii, dostęp: 2.02.2010.

51 Podaję za: M. Castells, Galaktyka Internetu. Reflekcje nad Internetem, biznesem i społeczeństwem, Poznań 2003, s. 135-153.

52 Za: D. Kotowicz, Internet - szanse i zagrożenia dla demokracji, w: Społeczna przestrzeń Internetu, red. D. Batorski, M. Marody, A. Nowak, Warszawa 2006, s. 287. 
niem z Internetu, a uczestnictwem w życiu publicznym prowadzili m.in. J. E. Katz, R. E. Rice i P. Aspden (2001) $)^{53}$.

D. Batorski (2006), korzystając z danych zawartych w Diagnozie Społecznej $2005^{54}$, przytacza wyniki opisujące związek między korzystaniem z sieci a udziałem w wyborach; angażowaniem się na rzecz społeczności lokalnej; uczestnictwem w zebraniach i zabieraniem w nich głosu, a także przynależnością do organizacji i zajmowaniem w nich jakiś funkcji. Dane pokazują, że Internauci są bardziej aktywni niż inne grupy, w następujących proporcjach: jeśli chodzi o angażowanie się na rzecz lokalnej społeczności, w stosunku 20\% do 14\%; uczestnictwo w zebraniach $24 \%$ do $17 \%$ i zabieranie w nich głosu $43 \%$ do $36 \%$. Jeśli chodzi o przynależność do organizacji i sprawowanie w niej funkcji stosunek (też z przewagą uczestników sieci) wynosi $17 \%$ do $10 \%$. W obszarze, który interesuje nas najbardziej, czyli partycypacji politycznej - opisywanej poprzez udział $\mathrm{w}$ referendum akcesyjnym ${ }^{55}$ - stosunek deklarujących uczestnictwo to ponad trzy czwarte $(76 \%)$ spośród osób korzystających z sieci do 59\% rekrutujących się z grupy niekorzystających z Internetu ${ }^{56}$. Podobne wnioski odnajdujemy u przywoływanej już A. Turskiej (2006), która cytując badania Institute of Technology ${ }^{57}$, pisze o Internecie jako znakomitym miejscu na prowadzenie kampanii wyborczych i kontaktu organizacji politycznych z sympatykami i elektoratem. Tą tezę uzasadniają zdaniem autorki wyniki badań, z których wynika, że ludzie używający Internetu, zdecydowanie częściej głosują w wyborach ${ }^{58}$.

53 Także J. E. Katz, R. E. Rice, Social consequences of the Internet, MIT Press, Cambridge 2002.

54 D. Batorski, Korzystanie z nowych technologii: uwarunkowania, sposoby i konsekwencje, w: Diagnoza społeczna 2005: Warunki i jakość życia Polaków, red. J. Czapiński, T. Panek, Warszawa 2006, s. 269-297.

55 Które odbyło się w czerwcu 2003, przed przystapieniem Polski do struktur Unii Europejskiej.

56 Por.: D. Batorski, Cyfrowy podziat w Polsce: Nowe technologie a szanse zyciowe $i$ wykluczenie społeczne, w: Społeczna przestrzeń Internetu, red. D. Batorski, M. Marody, A. Nowak, Wydawnictwo Szkoły Wyższej Psychologii Społecznej „Academia”, Warszawa 2006, s. 332-333. Por. także: za: D. Batorski, Podstawy społeczeństwa informacyjnego $w$ Polsce, w: Wymiary życia społecznego, red. M. Marody, op. cit., s. 469-491.

57 Przeprowadzone w roku 1997 na 11700 użytkownikach Internetu.

58 Ponad 20\% więcej obywateli-internautów (w stosunku do udziału w całym społeczeństwie), bierze udział w wyborach - podaję za: A. Turska, Marketing polityczny, w: St. Michalczyk, Media i komunikowanie w społeczeństwie demokratycznym. Szkice medioznawcze, Sosnowiec 2006, s. 205. 
Również w Diagnozie Społecznej 2009, autor jednego z podrozdziałów dotyczącego korzystania z technologii informacyjno-komunikacyjnych - D. Batorski, jednoznacznie potwierdza: „wśród osób, które mogły głosować w ostatnich wyborach parlamentarnych w 2007 roku częściej głosowały osoby korzystające z internetu niż te, które z niego nie korzystają - deklarowany udział w wyborach był o około 10 punktów procentowych wyższy wśród internautów. Można też było [też] zaobserwować bardzo dużą aktywność internautów w kampanii wyborczej"59.

\section{Podsumowanie}

Podsumowując powyższe rozważania, można zapytać: co na to wszystko politycy? Ci, którzy w każdej niemalże kampanii wyborczej (rzadziej poza nią) deklarują żywe zainteresowanie młodymi? Którzy za wszelką cenę starają się udowodnić społeczeństwu - wyborcom, młodzieży i sobie samym, żywotne zatroskanie sprawami młodych dorostych ${ }^{60}$. W ostatnich wyborach parlamentarnych, po raz kolejny byliśmy świadkami wzmożonego zainteresowania się, tą czasem zagubioną, czasem odrzuconą, czy zaniedbywaną lub po prostu zapomnianą grupą wyborców. Znów stali się oni „ważni dla świata”, przede wszystkim dla tych, którym zależy na jak najszerszym poparciu społecznym. Niestety po raz kolejny okazało się, że koniec kampanii oznacza dla młodych początek odsuwania ich na dalszy plan.

Ale można i należy także zapytać młodych o to, czy są świadomi intencji, metod i technik, jakie wobec nich stosują politycy zabiegający o ich głosy? Czy dysponują politycznym rozeznaniem? Czy mają wystarczającą wiedzę o mechanizmach, czy posiadają niezbędny kapitał społeczny, aby dokonać rzeczowej oceny sytuacji i - co równie ważne - skutecznie się przed tym oddziaływaniem bronić?

59 Stosunek 65,2 do $74,8 \%$ - to różnica pomiędzy internautami a osobami niekorzystającymi z Internetu pod względem aktywności społecznej (wyborczej). Za D. Batorski, Diagnoza społeczna 2009, op. cit., s. 302, http://diagnoza.com/pliki/raporty/Diagnoza_raport_2009.pdf, dostęp 30.11.2010.

60 [Politycy] „teraz na początku kampanii zwracają się do młodych. Jarosław Kaczyński przemawia na tle młodych, szef MSZ Radosław Sikorski próbuje mówić młodzieżowym slangiem. Po co to wszystko?" Zob. m.in. rozmowa Pawła Wrońskiego z prof. Bogdanem Wojciszke z SWPS - Politycy chca być młodzi, „Gazeta Wyborcza" 9-10.07.2011, s. 6. 
Teoretycznie - jak wykazano - choćby poprzez dostęp do najnowszych technologii komunikacyjnych (Internet, portale społecznościowe, fora dyskusyjne, Projekt Demokracja 2.0), mają oni możliwość recenzowania poczynań rządzących. Przejawiania własnej inicjatywy (także ustawodawczej), przedstawiania własnych rozwiązań. Ale do tego konieczne są niezbędne zasoby - chociażby kapitał intelektualny. Ten ostatni, zdobyć powinni w rodzinach, ale także w jednej z najważniejszych państwowych instytucji powołanej do nauczania - szkole. W związku z tym, zapytać należy także: czy znajdują wystarczające wsparcie merytoryczne w szkole, u swoich pedagogów, by stawać się świadomymi uczestnikami życia politycznego? Idąc dalej, czy właśnie ewentualne pozbawienie tegoż wsparcia, nie jest jedną z najważniejszych przyczyn ich politycznego wycofania, alienacji?

Nie sposób wyczerpująco odpowiedzieć na powyższe pytania w ramach tego artykułu. Ale mogą one być ważkim punktem odniesienia dla wszystkich, którym zależy na zapewnieniu ciagłości reprodukcji społecznej, na propagowaniu wartości, jaką jest aktywna postawa obywatelska, a w konsekwencji - efekt na który wszyscy czekamy: profesjonalizacja naszego życia politycznego.

\section{Bibliografia}

Batorski D., Cyfrowy podziat w Polsce: Nowe technologie a szanse życiowe i wykluczenie społeczne, w: Społeczna przestrzeń Internetu, red. D. Batorski, M. Marody, A. Nowak, Wydawnictwo Szkoły Wyższej Psychologii Społecznej „Academia”, Warszawa 2006,.

Batorski D., Korzystanie z nowych technologii: uwarunkowania, sposoby $i$ konsekwencje, w: Diagnoza spoteczna 2005: Warunki i jakość życia Polaków, red. J. Czapiński, T. Panek, Warszawa 2006.

Batorski D., Podstawy społeczeństwa informacyjnego w Polsce, w: Wymiary życia spotecznego. Polska na przetomie XX X XXI wieku, red. M. Marody, Warszawa 2007.

Brylczak M., Od propagandy do manipulacji. Ksztaltowanie wizerunku polityków $w$ mediach tradycyjnych i nowoczesnych, w: Wartości w polityce. Między sprawnościq a normalnościq, red. J. Miluska, w druku.

Castells M., Galaktyka Internetu. Reflekcje nad Internetem, biznesem i spoteczeństwem, Poznań 2003.

Dziubińska A., Ksztattowanie świadomości obywatelskiej na przykładzie wspótpracy politologicznych kół naukowych nauczycielami WOSu i historii, w: Szkice politologiczne - publikacja pokonferencyjna I Przegladowej Konferencji Politologicznych Kót Naukowych „Politeja”, Kraków 2008. 
Encyklopedia Pedagogiczna XXI w., t. III, Wyd. Żak 2004.

Gallas B., Pokolenie chaosu i nadziei. Socjalizacja w warunkach zmiany społecznej, w: Młodzież a dorośli. Napięcia między socjalizacja a wychowaniem, red. R. Kwiecińska, M. Szymański, Kraków 2001.

Giroux H. A., The a abordoned generation. Democracy beyond the culture of fear, New York 2003.

Goban-Klas T., Media i komunikowanie masowe. Teorie i analizy prasy, radia, telewizji i Internetu, Warszawa 2006.

Grabowska M., Poza politykq i demokracja, w: K. Koseła, Młodzież szkolna o rynku i demokracji, Warszawa 1999.

Jaklewicz K., Konsumenci, Generacja Y, „Wysokie Obcasy” dodatek do „Gazety Wyborczej", 30 lipca 2011, s. 28-30

Karnowski M., Mistewicz E., Anatomia władzy, Warszawa 2010.

Katz E. J., Rice E. R., Social consequences of the Internet, MIT Press, Cambridge 2002.

Kojder A., Jedna Polska?, WAM, Kraków 2006.

Kołaczek B., Aspiracje edukacyjne i możliwości ich realizacji, w: Pokolenie wygranych? Dzieci i młodzież $w$ procesie transformacji społeczno-gospodarczej i politycznej Polski, red. J. Sztumski, Katowice 2001.

Kotowicz D., Internet - szanse i zagrożenia dla demokracji, w: Społeczna przestrzeń Internetu, red. D. Batorski, M. Marody, A. Nowak, Warszawa 2006.

Offe C., Politische Legitimation durch Mehrheitsentscheidung?, w: B. Guggenberger, C. Offe, An der Grenzen der Mehrheitsdemokratie. Politik und Soziologie der Mehrheitsregel, Westdeutscher Verlag GmbH, Opladen 1984; za: B. Włodawiec, Claus Offe o politycznej legitymizacji poprzez decyzję większości, http://www.psychologia.net.pl/artykul.php?level=162, dostęp: 1.02.2009.

Ogryzko-Wiewiórkowska M., Świat dla młodych u progu nowego wieku, w: Młodzież $w$ kontekście formowania się nowoczesnych społeczeństw, red. W. Wawro, KUL 2004.

Ossowska M., Wzór obywatela w ustroju demokratycznym, Zarząd Główny Towarzystwa Uniwersytetu Robotniczego, Warszawa 1946.

Ostałowska L., Młodzież odłaczona, „Gazeta Wyborcza”, nr 202, wyd. 30.08.2003, „Gazeta Świąteczna”.

Pawełczyk P., Socjotechniczne aspekty gry politycznej, Poznań 2000.

Porębski L., Elektroniczne oblicze polityki. Demokracja, państwo, instytucje polityczne w okresie rewolucji informacyjnej, Kraków 2001.

Putnam R., Leonardi R., Nanetti R. Y., Demokracja w działaniu: tradycje obywatelskie we współczesnych Włoszech, Znak, Kraków, Fundacja im. Stefana Batorego, Warszawa 1995.

Skarżyńska K., Człowiek a polityka. Zarys psychologii politycznej, Scholar 2005. 
Sobkowiak L., Świadomość i socjalizacja polityczna. Anatomia socjalizacji politycz$n e j$, w: Studia z teorii polityki, red. W. A. Jabłoński, L. Sobkowiak, t. I.

Kompetencje medialne społeczeństwa wiedzy, red. W. Strykowski, W. Skrzydlewski, Poznań 2004.

Szafraniec K., Polska młodzież: między apatia, partycypacja a buntem, w: A. Kojder, Jedna Polska?, WAM, Kraków 2006.

Sztompka P., Dekalog obywatela, „Gazeta Wyborcza”, nr 8, 10 stycznia 2004.

Turska A., Marketing polityczny, w: St. Michalczyk, Media i komunikowanie w spoteczeństwie demokratycznym, Szkice medioznawcze, Sosnowiec 2006.

Wroński P., Politycy chca być młodzi, „Gazeta Wyborcza”, 9-10.07.2011.

Wrzesień W., Jednostka - rodzina - pokolenie. Studium relacji międzypokoleniowych, Poznań 2003.

Zielińska A., Nastoletni uczniowie o demokracji. Uwarunkowania społeczno-demograficzne i edukacyjne pogladów młodzieży. Wydawnictwo UW 2008.

Strony www, artykuły prasowe:

Projekt aktualizacji strategii państwa dla młodzieży na lata 2003-2012, http://bip.men.gov.pl/men_bip/akty_projekty/projekt_strategii_ala_mlodziezy_2003-12.pdf, dostęp 1.07.2011.

Batorski D., Diagnoza Społeczna 2009, http://diagnoza.com/pliki/raporty/Diagnoza_raport_2009.pdf, dostęp 30.11.2010.

Gołębiowski B., Edukacja polityczna - kultura polityczna, „Realia”, nr 5, październik 2009, http://realia.com.pl/dzial_8/artykul_22.html, dostęp 29.11.2009.

http://squat.net.ascii, dostęp 2.02.2010.

http://www.ceo.org.pl/portal/epio_dokument?docId=35419, dostęp 24.02.2010.

Manifest. Zespół projektu Demokracja 2.0, http://www.demokracja20.pl/manifest/, dostęp 2.02.2010.

http://www.demokracja20.pl/monitoring/, dostęp 8.12.2010.

http://www.freechild.org/abandoned.htm, dostęp 1.03.2009.

Młodzież od wykluczenia do włqczenia - wytyczne do działań, http://www.lomza.pl/bip//zalaczniki/art/061124085121.pdf, dostęp 27.06.2011.

http://www.marki.net.pl/interpelacja-obywatelska-1090, dostęp 8.11.2008.

Konstytucja RP $z$ dnia 2 kwietnia 1997 r. (Dz. U. Nr 78, poz. 483), http://www.pkw.gov.pl/gallery/19/91/72/199172/Konstytucja_Rzeczypospolitej_Polskiej.pdf, dostęp 20.06.2011.

Rozmowa z prof. Sztanderska Urszula ,,Raport o rozwoju społecznym Polska 2007 - Edukacja dla pracy", http://www.skp_nansen.republika.pl/artykul_mk5.pdf, dostęp. 27.06.2011. 
http://www.urbact.pl/oprogramie.html, dostęp 8.07.2011.

Skarżyńska K., Świat to dżungla, http://wyborcza.pl/1,75515,9970435,Swiat_to_dzungla.html, dostęp 22.07.2011.

\section{The school of democracy - young people in society and politics. Exclusion or negligence?}

\section{Summary}

The paper attempts to show the role of young people in society and politics. It tries to approach young adults on one hand as subjects of politics with their consciousness, rights and obligations, and on the other as the objects of a wide range of social engineering, media and educational activities by politicians. Two significant phenomena concerning the young are briefly discussed, namely social capital and exclusion from political life. The latter can be interpreted either as an attempt to escape a reality that the young do not understand, or as their conscious choice and a substitute for freedom. The process of education is significantly contributed to (apart from the institutions dedicated to this purpose, such as school and family) by the media, in particular the modern media, or post-modern ones that provide a communication channel among the young, but also attract the politicians, who try to attract the attention of the young and win their support. The author concludes by saying that the social capital generated by educational institutions as well as by the "networks of mutual contacts' among the young can offer the best possible protection from the processes of alienation and exclusion that constitute a threat to democracy. 
